\title{
Credit Purchase Control System in Credit Purchase Control System Cheating in Limited Company Trans Burger
}

\author{
Achmad Fauzi ${ }^{1 *}$ and Iwan Setyawan ${ }^{2}$ \\ ${ }^{1}$ University of BSI, Indonesia \\ ${ }^{2}$ Kosgoro Institute of Business \& Informatics 1957
}

\begin{abstract}
Trans Burger Limited Company or more often called Wendy's is a chain of restaurants and international food franchises specializing in "Hamburger" food. The vision of Wendy's both Wendy's International and Wendy's Indonesia is "Quality is Our Recipe". Trans Burger is done on credit with terms of payment based on the initial agreement with the supplier. Purchases of goods are also conducted centrally at headquarters even though sales occur branches. In the Company's day-to-day operations. Trans Burger uses Trans Browser program. The Warehouse/Store function of the Trans Burger Company is responsible for making a purchase request in accordance with the existing inventory position in each warehouse/store. Purchase Request at Trans Burger is commonly called Purchase Request (PR) created using Trans Browser system. From Supply Chain side, the control is done by making partial delivery Purchase order so that goods are not directly imported at once. In terms of Operation, the control is done by training the store manager on how to create a Receiving Voucher (RV), since the Receiving Voucher (RV) must be made in accordance with the street mail and the goods reality received by the store.
\end{abstract}

Keywords: Credit purchase; Control system; Inventory position; Trans burger

\section{Introduction}

Company productivity is an important thing, therefore in order to remain able to complete the need for development of a better information system. The development of the system could mean setting up a new system to replace the old system as a whole or improve the existing system. Companies usually have guidelines that should all run with existing systems, especially purchasing information systems. Purchase information system should be implemented in accordance with the rules set by the company where the purpose is to establish accountability and to provide complete information about the goods received and ordered because of the accuracy in accounting records will help the realization of efficiency and effectiveness of work, one of which is perceived to be very important for the company is how the purchasing information system of a business activity goes well.

The purchasing information system involves several sections dealing with purchasing issues. If each part does not work properly in accordance with the prevailing system, then it is likely to make mistakes, either the purchase or recording activities. Existing systems and standard purchasing procedures are very important in the implementation of purchasing activities, so that future purchasing activities can be properly accounted for. Have a good system for existing procedures and rules to run properly according to the needs required by the relevant sections. This purchase cannot be ruled out in a company's operational activities, because the purchase is a procurement of goods that can be used for the needs of the company or can be sold back to other parties. Every company, whether a service company, a trading company, or a manufacturing company, in carrying out its operational activities always requires goods that procurement must be purchased from other parties (suppliers) and it is all implemented to support the effectiveness of the work of each related section. Trans Burger Company is a food and beverage company. The company realizes the importance of purchasing raw materials to support the company's operational activities in order to keep running. Buying activities are almost done every day, therefore there is a need to control the purchase system. This control is useful to minimize errors that occur and can help companies to achieve its goals.

\section{Company expansion trans burger}

The Burger Company or more often called Wendy's is a chain of international restaurants and food franchises specializing in "Hamburger" food. The company was founded in 1969 by Dave Thomas in Dublin, Ohio. Wendy's is now the third largest chain hamburger restaurant in the world, with nearly 6,700 restaurants in over 27 countries. In addition, Wendy's also famous with various diverse menu mainstay. So, it can attract customers to make Wendy's their favourite restaurant. The vision of Wendy's both Wendy's International and Wendy's Indonesia is "Quality is Our Recipe" (Quality is Our Recipe). Not only the quality of the food alone, but the quality of employees, food and so on that must remain in the guard so that consumers are satisfied with the services provided by Wendy's. We also want to be the best in terms of. The mission of Wendy's both Wendy's International and Wendy's Indonesia is "Understanding of our vision and how to make it a reality at Wendy's restaurant. The purchase of goods at the Trans Burger Company shall be made on a credit basis with terms of payment based on the initial agreement with the supplier. Purchases of goods are also conducted centrally at headquarters even though sales occur in branches. In the daily operations of PT. Trans Burger uses Trans Browser program.

Related Functions in Accounting System of Credit Purchase; The following is a comparison between the corresponding functions in the Credit Purchase Accounting System in accordance with those applied to the Trans Burger Company with associated functions in the Accounting System Lending System.

*Corresponding author: Achmad Fauzi, University of BSI, Ibi Kosgoro 1957, Indonesia, Tel: +62 2180649 600; E-mail: achmad_fauzioke@yahoo.com

Received August 03, 2018; Accepted September 20, 2018; Published September 28, 2018

Citation: Fauzi A, Setyawan I (2018) Credit Purchase Control System in Credit Purchase Control System Cheating in Limited Company Trans Burger. J Bus Fin Aff 7: 349. doi: 10.4172/2167-0234.1000349

Copyright: () 2018 Fauzi A, et al. This is an open-access article distributed under the terms of the Creative Commons Attribution License, which permits unrestricted use, distribution, and reproduction in any medium, provided the original author and source are credited. 


\section{Based on the applied trans burger company}

Warehouse/store functions: Warehouse/Store Function at PT. Trans Burger is responsible for making a purchase request in accordance with the position of inventory in the warehouse/store respectively. Purchase Request at Trans Burger Company is called Purchase Request (PR) which is made using Trans Browser system. Another function is to receive and store items that have been received from the supplier. Receipt report of goods at PT. Trans Browser is commonly called Receiving Voucher (RV) which is made using Trans Browser system.

Purchase function: Purchasing Function at PT. Trans Burger is responsible for obtaining pricing information, determining which suppliers to choose based on the best price and quality and issuing purchase orders to selected suppliers. Purchase Order Letter at PT. Trans Burger commonly called Purchase Order (PO) is made using the system Trans Browser

Accounting functions: Accounting Function at PT. Trans Burger is responsible for verifying the invoices coming from the supplier and recording the purchase transactions into the system for payment to be made by the finance department.

\section{Based on accounting credit system accounting literature}

Warehouse function: In the purchasing accounting system, the warehouse function is responsible for making a purchase request in accordance with the existing inventory position in the warehouse and for storing the goods received by the receiving function. For goods that are directly used (not held inventory goods in the warehouse), the request is filed by the wearer of the goods.

Purchase function: The purchase function is responsible for obtaining information on the price of the goods, determining the selected supplier in the procurement of goods, and issuing a purchase order to the selected supplier.

Acceptance function: In a purchasing accounting system, this function is responsible for examining the type, quality, and quantity of goods received from suppliers to determine whether or not the goods are accepted by the company. This function is also responsible for receiving goods from buyers arising from sales return transactions.

Accounting functions: Accounting functions related to the purchase transaction are the function of the debt register and the function of the inventory recorder. In the purchasing accounting system, the debt recording function is responsible for recording the purchase transactions into the cash out cash register and for holding an archive of source documents (cash out proof) that serves as a record of debt or holding a debit card as a debt help book. In the purchasing accounting system, the function of the inventory taker is responsible for recording the cost of goods purchased in the inventory card.

\section{Purchase request procedure}

In this procedure, the warehouse/store function has the task of submitting a purchase request in accordance with the position of inventory to the purchasing function by using a Purchase Request (PR) (Figures 1 and 2):

\section{Purchase order procedure}

In this procedure, the purchase function has the task of making a purchase order or Purchase Order (PO) then sends the letter to the

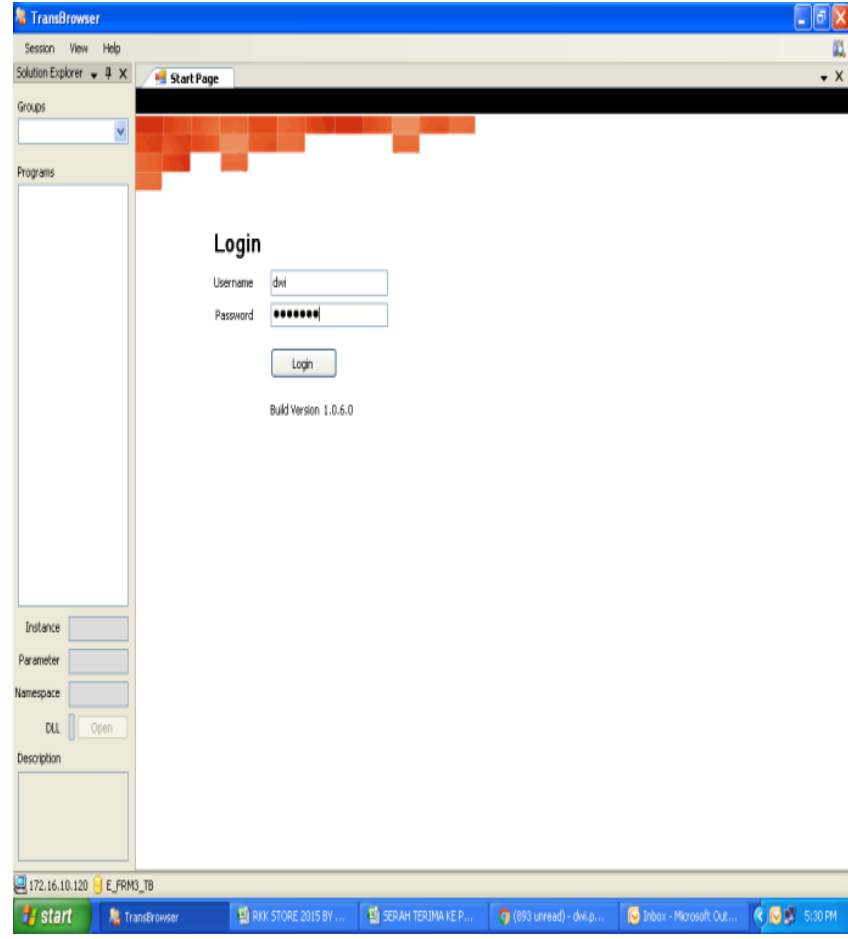

Figure 1: Display login system trans browser.

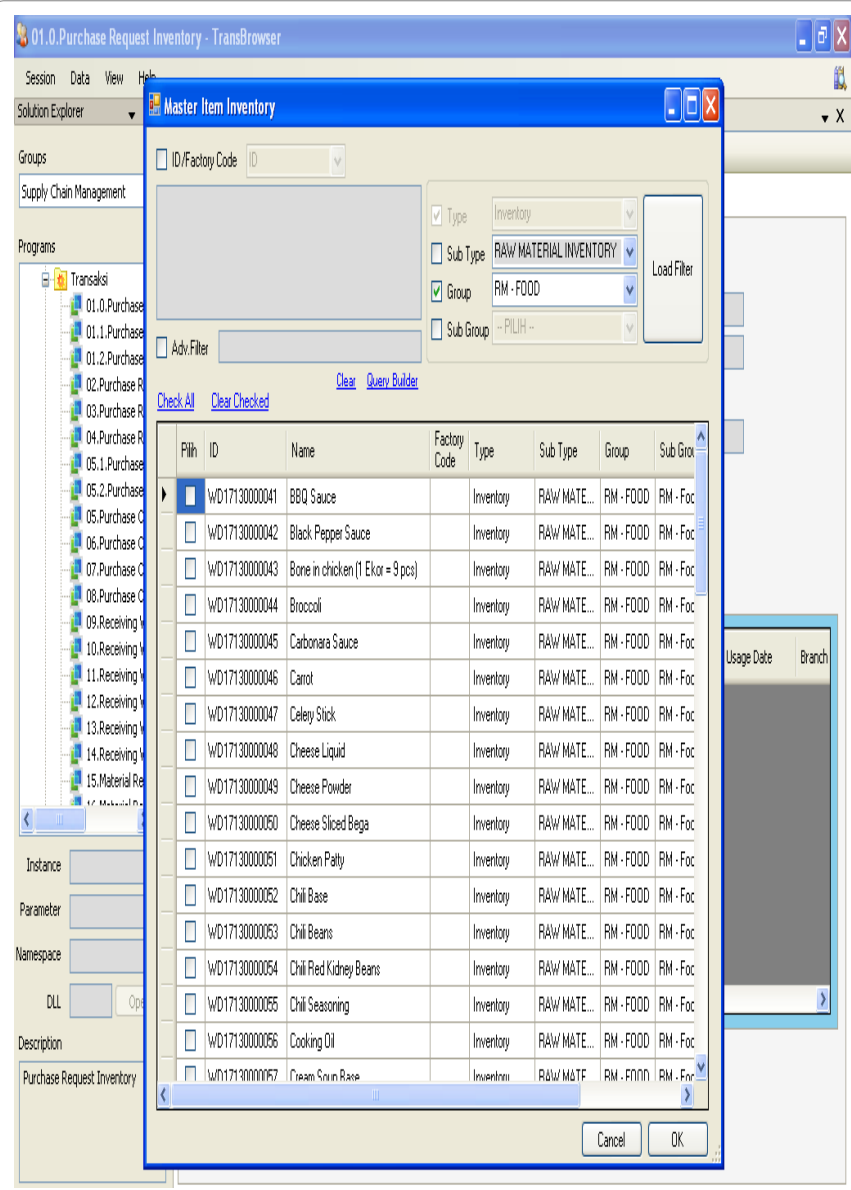

Figure 2: View when creating a purchase request. 
Citation: Fauzi A, Setyawan I (2018) Credit Purchase Control System in Credit Purchase Control System Cheating in Limited Company Trans Burger. J Bus Fin Aff 7: 349. doi: 10.4172/2167-0234.1000349

Page 3 of 7

selected supplier and provides information on the purchase order letter to the supplier, warehouse/store function and accounting function (Figure 3).

\section{Procedures for receiving goods (done by Warehouse Function/ Store)}

In this procedure, the warehouse/store function also has the task of receiving goods from suppliers. After receiving the goods, the warehouse/store function makes a receipt report (RV) and then deliver the Receiving Voucher (RV) to suppliers to attach to invoices to be received by the company (Figure 4 ).

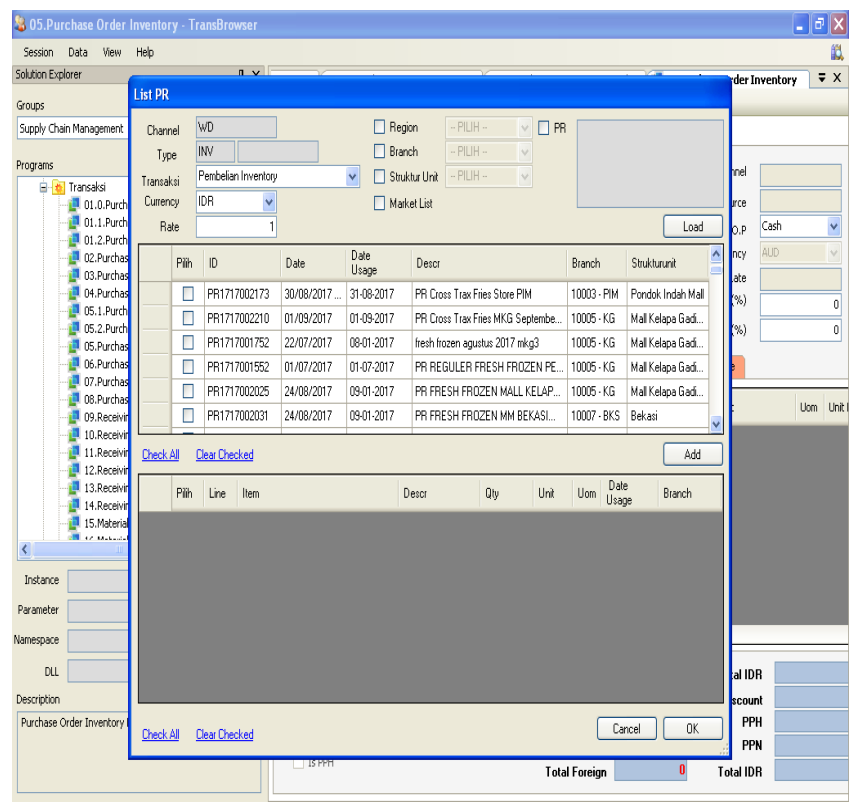

Figure 3: Views when creating a purchase order (PO).



Figure 4: Display when creating a voucher (RV)

\section{Debt registration procedure}

In this procedure, the accounting function has the task of verifying the invoice from the supplier in which there is also a Purchase Order (PO) received by the supplier when the purchasing function purchases and receives the Voucher (RV) received

by the supplier from the warehouse/store function at the time suppliers deliver goods. After that accounting functions submit invoices that have been inputted into the system Trans Browser to the finance for processing payment (Figure 5).

\section{Methodology}

\section{Research design}

In order to answer the initial questions, this study employed qualitative method by involving a case study. A case study is different from experimental study in some ways. The difference is experimental study typically involves two or more groups, while a case study involves single individual or group, and does not attempt to set up experimental and control groups. This is supported by Emilia who states that a case study design employed in "small scale, single scale". Focus on one particular instance of educational experience or practice.

Burgess describes, interviews as conversation with a purpose. Burns [1] claims, there are three types of interview generally used for action research. They are structured interviews, guided or semi-structured interviews and open interviews. Interview is transcriptions of openended interviews; this instrument unstructured text data obtained from transcribing audiotapes of interviews and observation is field listening song; this instrument unstructured text data and song taken during observation by the researcher.

In conducting a study, it is necessary to do research planning so that the research conducted can run well and systematically. Research design for the authors are all the processes used in planning and execution of research, it can be done by the authors in carrying out

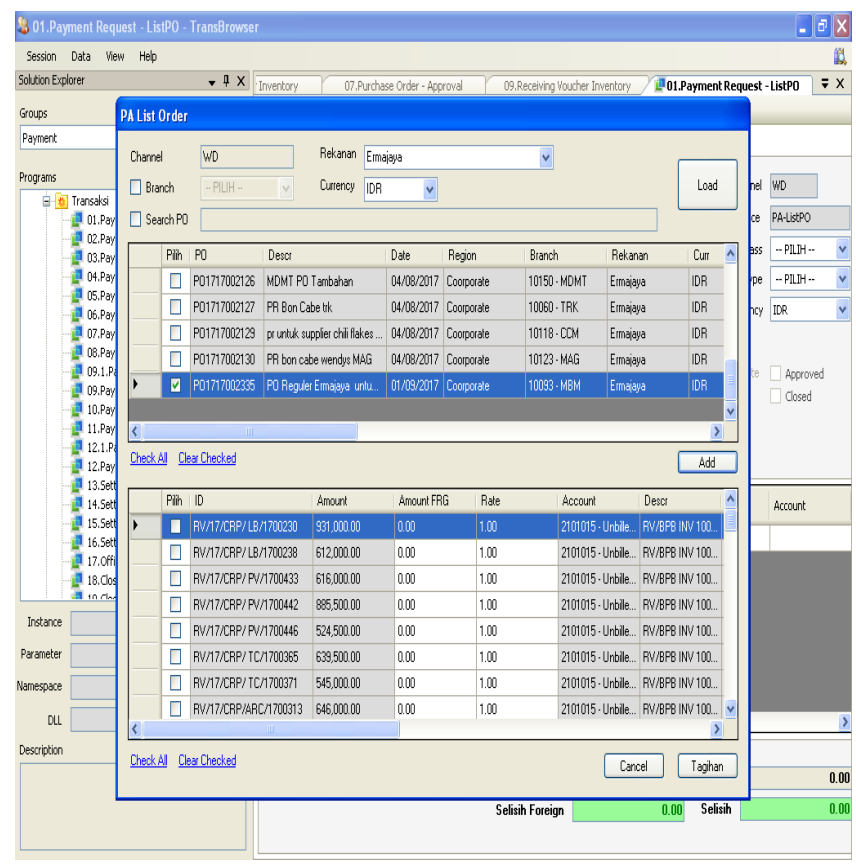

Figure 5: Views when creating a payable account (AP). 
research from planning to implementation of research conducted by selecting, collecting, and analyzing the data under study at a certain time. In each study is always faced with the opportunity to determine the population. Population is an object or subject that is in a region and meet certain conditions relating to research problems. The population in this study is all activities that occur in all accounting information systems in Trans Burger Company or Wendy's.

Sample is an accounting information system of credit purchase that is part of the number and characteristics possessed by the population. In this case the samples taken in the study are as follows:

1. Purchase Request data on a particular supplier.

2. Data Purchase Order on a particular supplier.

3. Receiving Voucher data on a particular supplier.

4. Invoice data provided by a particular supplier.

5. Interviewing company employees directly related to the research (warehouse, supply chain, and accounting department).

\section{Findings and Discussion}

In this study data analysis used is a qualitative data analysis model Miles and Huberman [2]. This analysis consists of three activities that occur simultaneously namely data reduction, data presentation, and withdrawal of conclusions/verification (Figure 6).

The following is the elaboration of the three flow of activities that occurred in the analysis of qualitative data proposed by Miles and Huberman:

\section{Data reduction}

Data reduction is defined as the selection process, focusing on simplification, abstraction, and "rough" data transformation arising from written notes on the ground. Data reduction persists throughout a qualitative-oriented project [3]. As long as the data collection takes place, there is a further reduction stage. This data reduction continues throughout the fieldwork, until a complete final report is compiled.

\section{Presentation of data}

The presentation of data is as a set of arranged information that gives the possibility of drawing conclusions and taking action [4]. The presentation of this data includes different types of matrices, graphs, networks, and charts. Everything is designed to combine information composed in a coherent and accessible form.

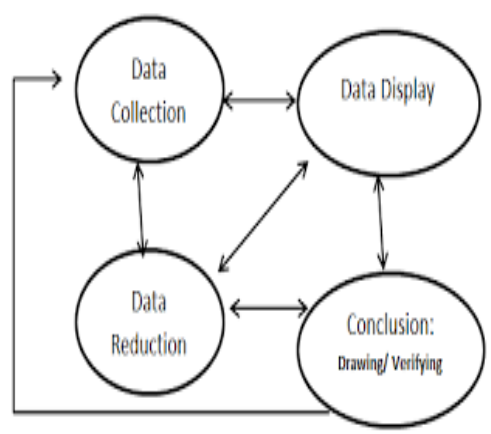

Source: Miles and Huberman. Qualitative Data Analysis (2014) p. 18 Figure 6: Data analysis components: Flow model.

\section{Attract conclusion/verification}

Since data collection, a qualitative analyser begins to record regularity, patterns, explanations, possible configurations, causal paths, and propositions. The competent researcher will deal with these conclusions loosely, openly, and skeptically. The conclusion is tested for its truth, its robustness, and its suitability [5].

Three major issues have been proposed: data reduction, data presentation, and conclusion / verification as intertwined before, during, and after data collection. For the working mechanism of the three flow analysis model Miles and Huberman can be seen in the following Figure 7:

\section{Data Analysis Components: Interactive Model}

In this sense, qualitative data analysis is an ongoing, repetitive, and ongoing effort. Data reduction problems, data presentation, and conclusions/verification are success stories in sequence as a series of follow-up analysis activities (Figure 8).

Here the author will explain about the image above:



Source: Miles and Huberman. Qualitative Data Analysis (2014) p. 20

Figure 7: Components of data analysis: Interactive model (Miles and Huberman, 1994)

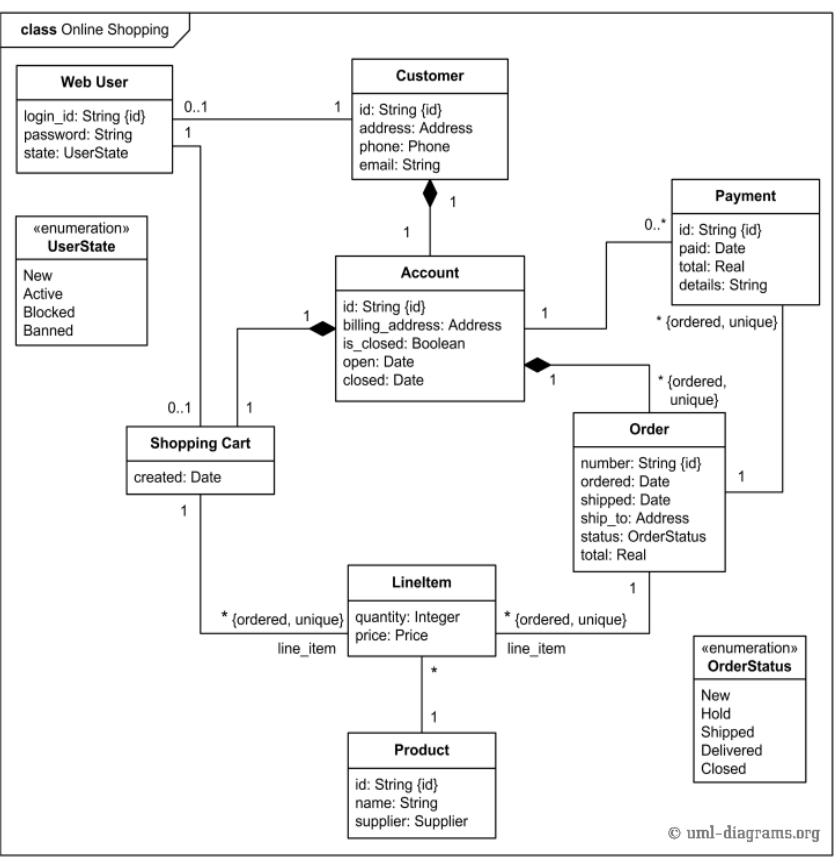

Figure 8: Credit purchase decomposition applied by trans burger company. 


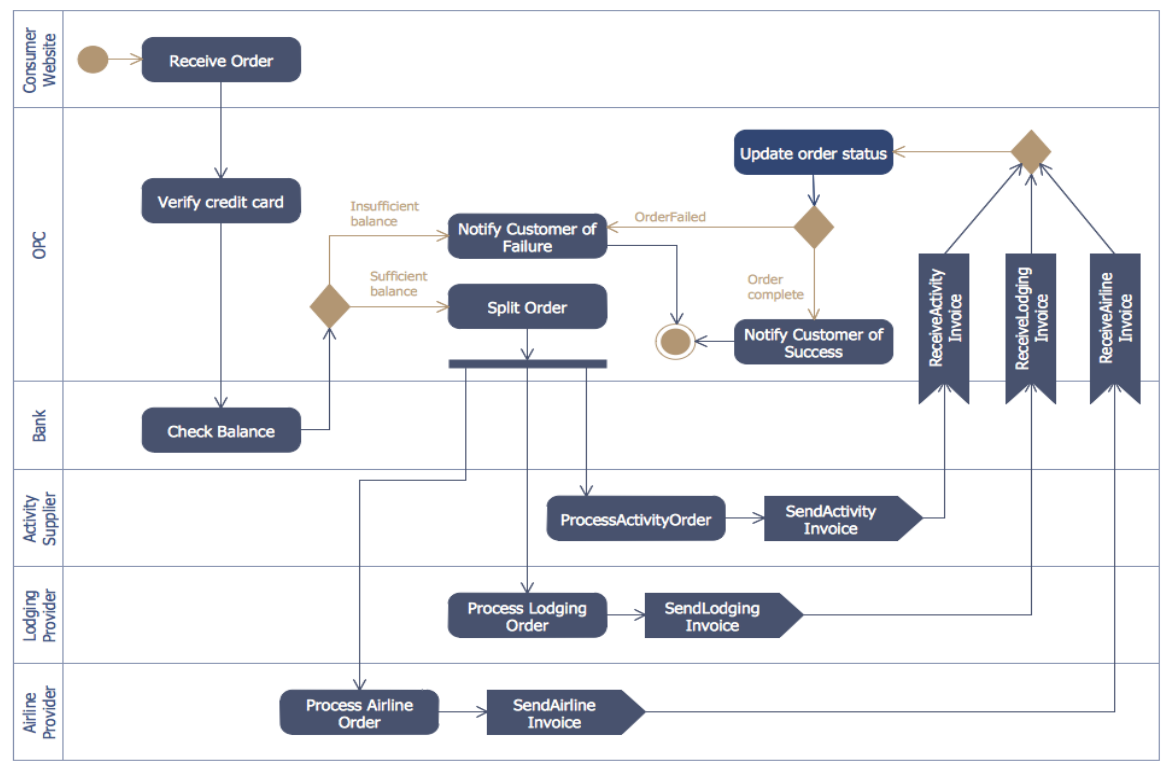

Figure 9: Activity diagram of purchase request procedure.

1) Credit purchase system: Purchase system applied by PT. Trans Burger is a credit purchase system. Credit purchases to suppliers with maturities of 30 days from the date the supplier processes the invoice on PT. Trans Burger [6].

2) Master: The master in question is the purchase system at PT. Trans Burger is controlled by the purchasing function. The purchase function that will enter data, such as supplier data and goods data.

3) Transactions: Transactions that occur are credit purchase transactions, such as purchase requests made warehouse / store functions and purchase order transactions made by the purchase function.

4) Acceptance of goods: Goods sent by suppliers are then accepted by the warehouse/store function.

5) Debt Listing: The accounting function will record the debt into the Trans Browser system upon receipt of invoice from the supplier.

6) Report: A report on the quantity of goods ordered from the supplier during a certain period is made by the purchasing function as evidence of liability to the management.

\section{Activity diagram of purchase of credit applied by trans burger company}

The following is an activity diagram of the credit purchase system at Trans Burger Company [7]:

Activity diagram of purchase request procedure: In this procedure, the store function submits a purchase request in accordance with the inventory position to the purchase function by using a Purchase Request (PR) request letter (Figure 9).

Activity diagram of purchase order procedure: In this procedure, the purchase function makes a purchase order or Purchase Order (PO) then sends the letter to the selected supplier and provides information on the purchase order letter to the supplier, warehouse/store function and accounting function. Once the supplier receives a Purchase Order (PO), the supplier will process the order (Figure 10) [8].

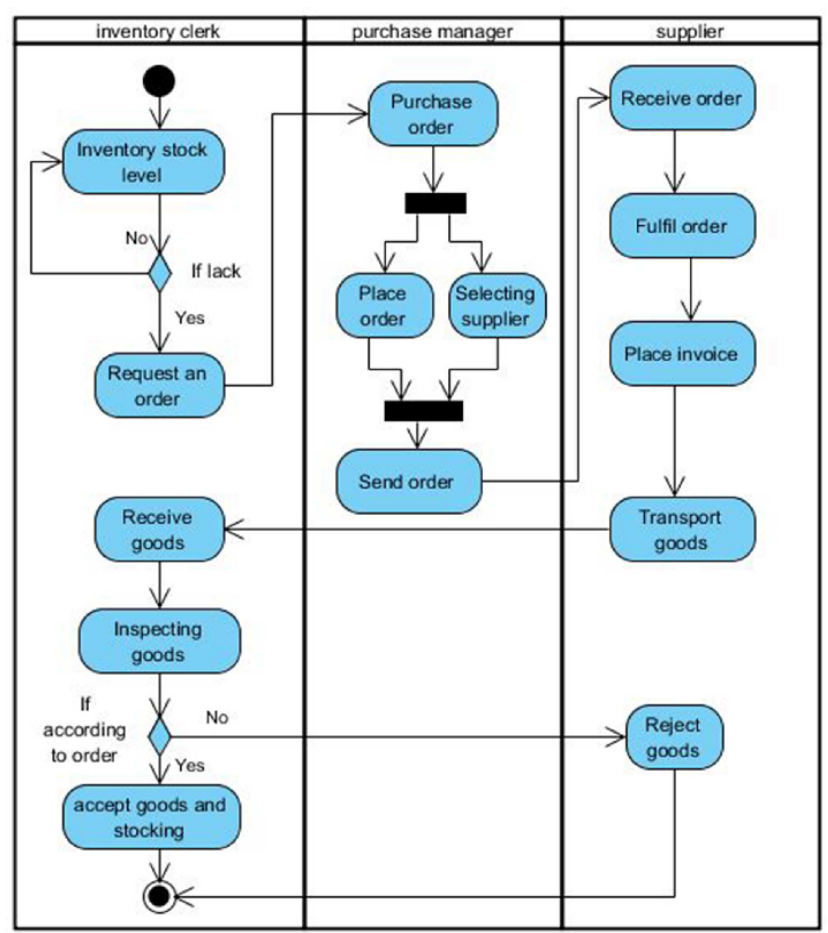

Figure 10: Activity diagram of purchase order procedure.

Activity diagram of goods receiving procedure: In this procedure, suppliers send goods orders and functions that receive goods from suppliers is a function store. Upon receipt of the goods, the store function prepares the Receiving Voucher (RV) report and then delivers the Receiving Voucher (RV) to the supplier to be attached to the invoice to be received by the company (Figure 11) [9].

Activity diagram debt listing procedure: In this procedure, the supplier will make invoices from goods that have been ordered 


\section{Data Flow Diagrams}

Converting Business Activity Models

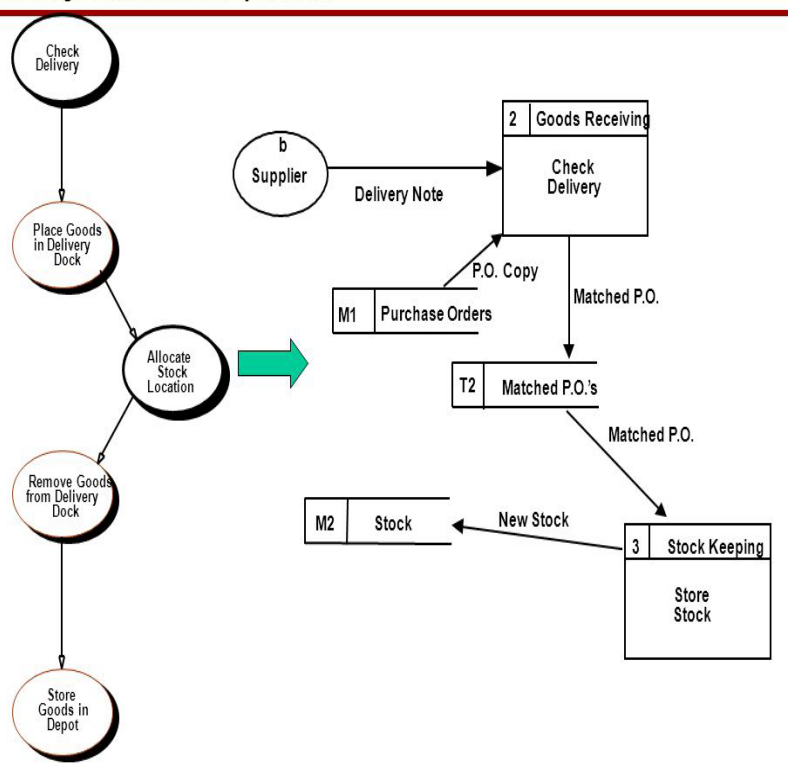

Figure 11: Activity diagram of goods receiving procedure. by the company and submit the invoice to the accounting function. Once the accounting function receives the invoice, the accounting function processes the invoice. Then the accounting function to submit invoices that have been inputted into the system Trans Browser to the financial section for processing payment (Figure 12) $[10]$.

Activity diagram making report: As evidence of accountability to the boss, the monthly purchasing function will produce a report to find out how many items are ordered from suppliers (Figure 13) [11].

\section{Concluding Remarks}

Based on the results of research conducted by the author, the authors draw the following conclusions:

1. Procedure of credit accounting system purchasing that has been running on Trans Burger Company still not in accordance with the literature. The mismatch is not one of the functions of the reception function. As a result, there are several times the difference between the goods received from the supplier and the items recorded on the system.

2. Control of credit purchases in Trans Burger Company is still not effective because of lack of one function in the credit purchase accounting system in the form of acceptance functions including the dual function of the store function which doubles the reception function. So, although there are activities from the Operational in

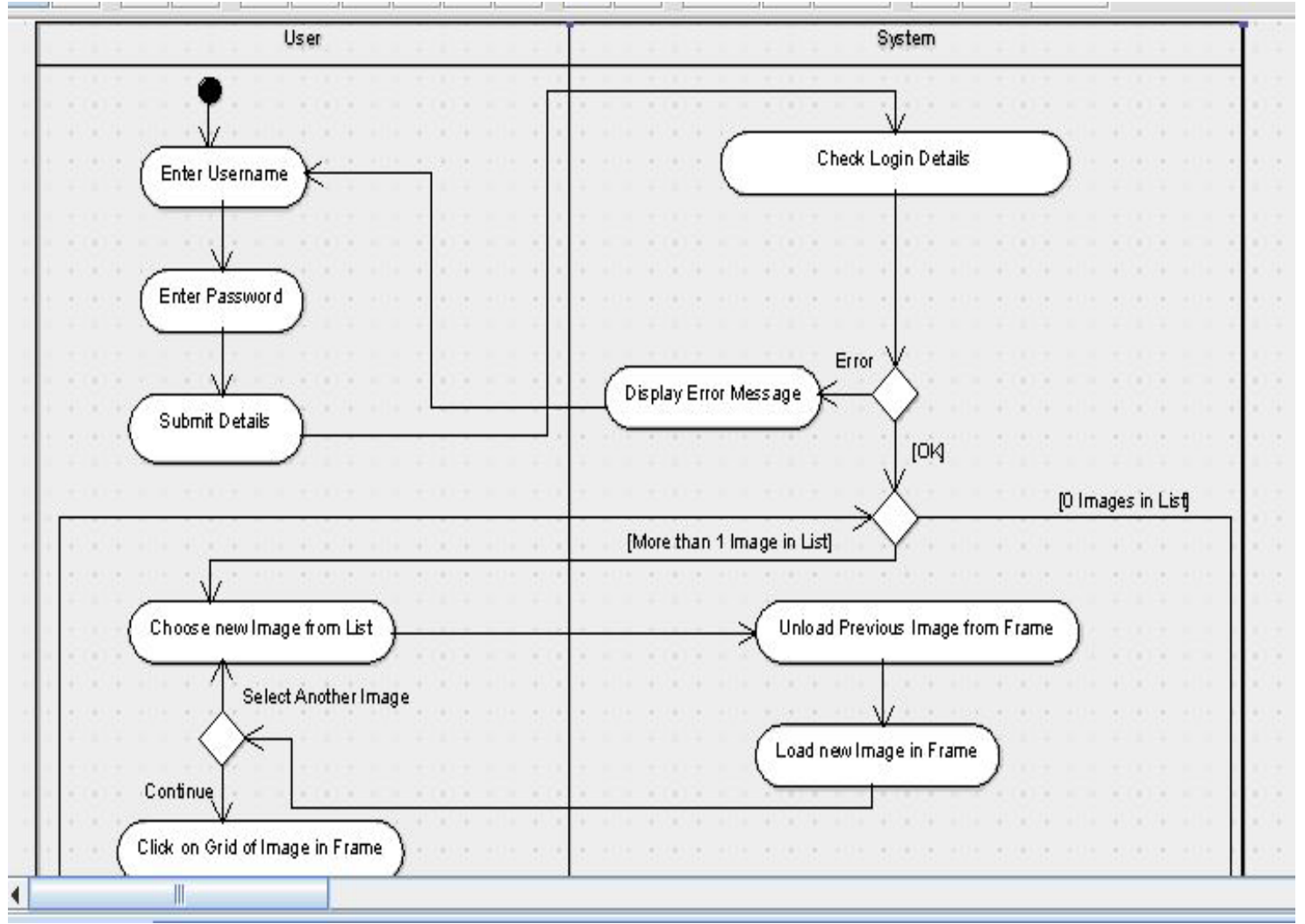

Figure 12: Activity diagram debt listing procedure. 
Citation: Fauzi A, Setyawan I (2018) Credit Purchase Control System in Credit Purchase Control System Cheating in Limited Company Trans Burger. J Bus Fin Aff 7: 349. doi: 10.4172/2167-0234.1000349

Page 7 of 7

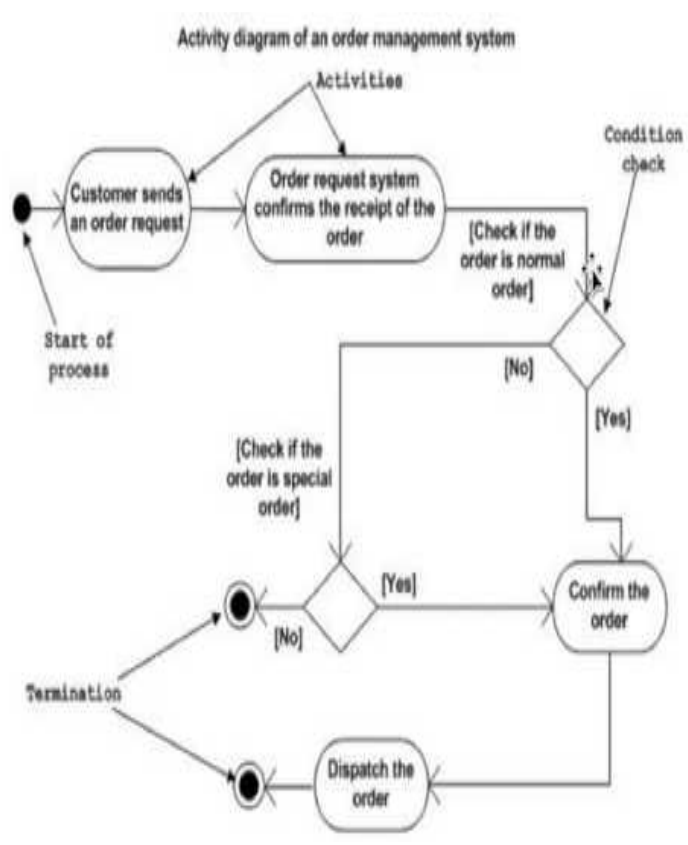

Figure 13: Activity diagram making report. the form of training to the store manager regarding the procedure of receipt of goods, but because of the double function there remains the possibility of fraud, so the company's goal to earn profit is not achieved optimally.

\section{References}

1. Burns BR (1994) Introduction to research methods. Longman, Melbourne.

2. Miles MB, Huberman AM (1984) Qualitative data analysis: A sourcebook of new methods. SAGE Publications Inc, California.

3. Suwardjono (2014) Accounting theory of engineering financial reporting. (3rd ed), BPFE Yogyakarta, Yogyakarta.

4. Haygren CT, Harrison WT, Robinson MA (2007) Accounting. Erlangga Publisher, Jakarta.

5. Yusuf AH (2011) Accounting basics. Sekolah Tinggi Ekonomi Yayasan Keluarga Pahlawan Negara, Yogyakarta.

6. Diana A, Setiawati L (2010) Indonesian taxation concepts, applications and practical guides. Andi Offset, Yogyakarta.

7. Susanto A (2013) Accounting information system. Lingga Jaya, Bandung.

8. Jacob (2012) Introduction to information systems. Graha Ilmu, Yogyakarta.

9. Sutabri T (2012) Information system concepts. Andi. Yogyakarta.

10. Augustine Mujilan (2012) Accounting information systems theory and insight in the world elekroniks. WIMA Press, Madiun.

11. Merriam SB (1991) Case study research in education: A qualitative approach. University of Michigan, USA. 